\title{
التفكير الجانبي وعلاقته بكفاءة المواجهة لدى طلبة معهد الفنون البميلة
}

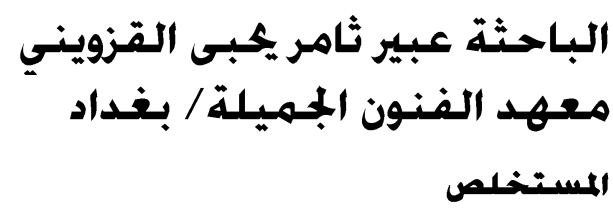

هدفت الدراسة التعرف على التفكير الجانبي لاى طلبة معهز الفنون الجميلة ، والتعرف على كفاعة المواجهة لدى طلبة معهد الفنون

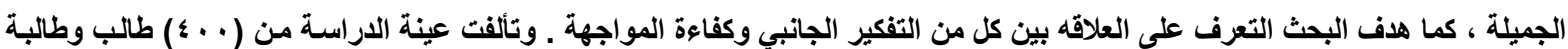

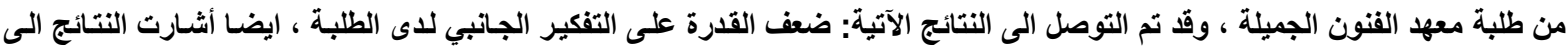
تمتع الطلبة بلرجة من كفاءة المواجهة ، كما أثارت الدراسة الى وجود علاقة ارتباطية بين متغيرات البحث .

Abstract/ The aim of the study was to identify the thinking and the basis of the students of the Institute of Fine Arts and to identify the efficiency of continuity among the students of the Institute of Fine Arts. A study about the student $(\xi \cdots)$ students from the Institute of Fine Arts, has been reached the following results: Students were able to think sideways, and their role in treatment.

\section{أولا: مشـكـة البحثث}

تركز اعتماد الاتجاه التقليدي في التربية دائما على التفكير المباثر او مـا يسمى بـ (التفكير العمودي او

الر اسي) و هو التفكير الذي يحرك الفرد الى الأمام بخطوات تتابعيه ومنطقية ومدروسة بشكل جديد ويستبعد هذا

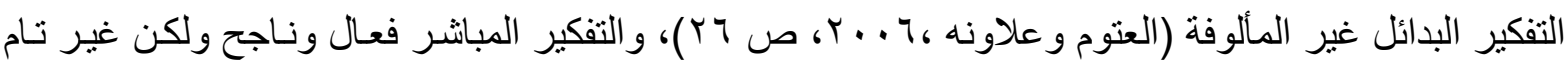
و هو ممتاز في حالات كثيرة لكنه غير كاف، لان هذا الأسلوب لا ينطوي على الاهتمام الكافي بجوانب التفكير التوليدية و المنتجة و المبدعة ، ومع ذلك يجب التأكيد على قيمـه أسـلوب التفكير هذا وأهميته عند استخدامه في مكانه الصحيح أما الخطر فيكمن في عد هذا الأسـلوب وحده كافيـا والسـاح لـه بالسيطرة على جميع محاولاتتـا

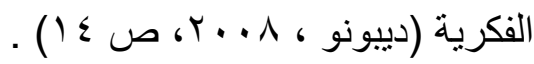

ونظـر المـا يتميـز بـه العصـر الحـالي مـن تغيـرات سـريعة ومتلاحقـة أدت الـى العديـد مـن المشكلات

و الصر اع النفسي الذي يو اجه الفرد في التو اصل مع الآخرين ، لذا يتوجب على الفرد ان يكون على قدر عـال

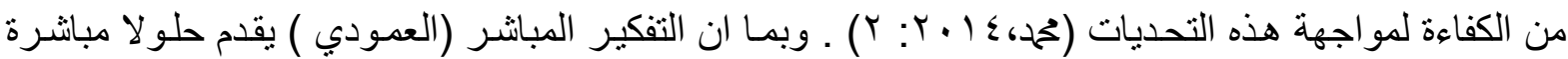
لكنها ليست مثالية ،كما انه بطبيعته غير قادر على توليد أفكار جديدة بـل معيقا لها كان من الأفضـل ان نذهب بالاتجاه المعاكس والمتمثل بـ(التفكير الجانبي) إذ ان عدم التز ام التفكير الجـانبي باتجـاه محدد يجعلـه قادر ا على

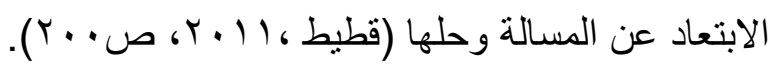

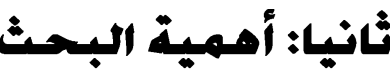

تحتل مسألة التفكير في علم النفس وفي علوم أخرى وفي الحياة بوجهه عام مكانهـ رئيسـة ، لان مهمـة التفكير تكمن في إيجـاد حلول مناسبة للمشكلات النظريـة و العمليـة الملحـة التـي يواجهها الإنسـان في الحيـاة

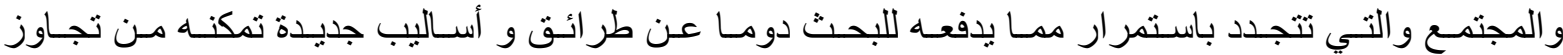
الصعوبات و العقبات التي تظهر و التي يحتمل ظهور ها في المستقبل ويتيح له ذلك فرصا للتقدم والارتقاء. . 
وبمـا ان التفكير كعمليه معرفيـه قد حظي باهتمـام العاملين في مجـال علم ألنفس فـان تتميته تعد هدفا

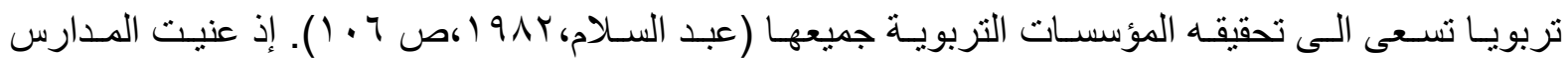
الفلسفية والفكرية والتربوية كافه بتنمية التفكير لدى المتعلمين وان هناك إجماعا بين العلمـاء والمربين بضرورة تتميه قدر اتهم العقلية وتطوير مهار اتهم الفكرية و أعداد بر امج تعليمية وتدريبيه بهدف بناء جيل مفكر من الطلبة

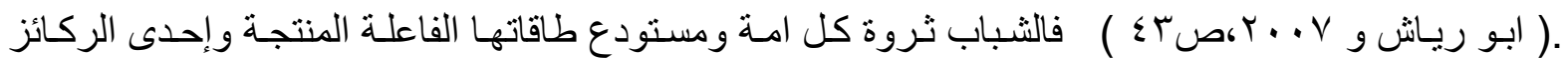
الأساسية في تحقيق التتمية الاقتصـادية والاجتماعية القادرة على إحداث التغيير والتطوير في مجالات الحياة جميعها.

ويعد التفكير الجانبي احد أنماط التفكير وهو يرتبط بالعالم (ادوارد ديبونو) الذي ابتدع مصطلح التفكير الجانبي (lateral thinking) و الذي يعني البحث لحل المشاكل بأساليب غير تقليديه وقد سماه كذلك ليميزه عن

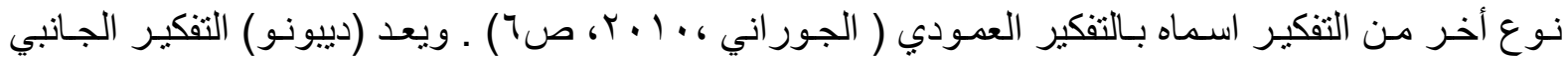
اتجاها عقليا يتضمن الرغبة في محاوله النظر الى الأشياء بطر ائق متعددة ، ويتضمن كذلك فهم الكيفية التي يستخدم فيها العقل النماذج ، ومدى الحاجة للتخلص من النماذج المؤطرة في التفكير والتحول الى نمـاذج أخرى

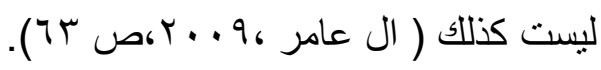

ألا ان بعض الناس غير راضين عن التفكير الجانبي لأنهم يشعرون انه يهدد صحة التفكير الراسي ، ألا

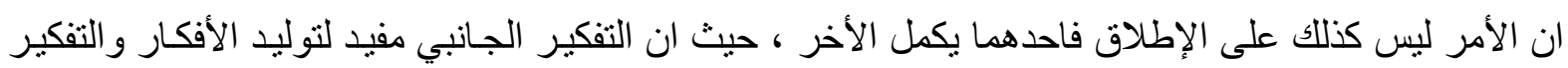
الر اسي مفيد لتطوير هـا ، كمـا ان التفكير الجـانبي يعزز فعاليه التفكير الر اسـي من خـلال تقديم أكثر من خيـار والتفكير الر أسـي يضـاعف فعاليه التفكير الجانبي من خـلال الاستخدام الجيد للأفكار المتولدة debono ) 19 Y r.prv) فالأفكار الجديدة بحاجـة إلىى تفكير جـانبي لأن العمودي مُحاصَر بحدود بنيويـة تمنعـه من أداء هذه المهـة و لا

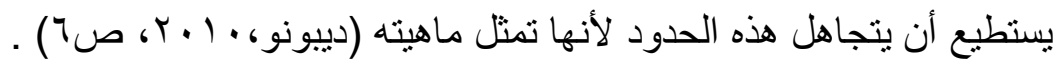
وقد أطلق (دييونو) على هذا النوع من التفكير بـ (الإبداع الجاد) وذللك للتفريق بين الإبداع المعتمد على

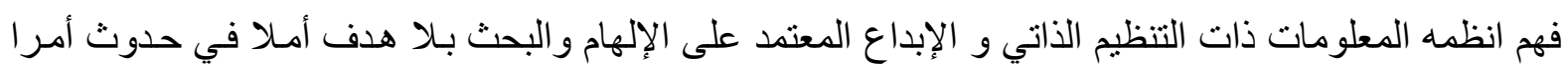

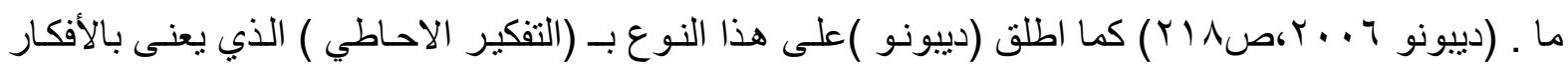

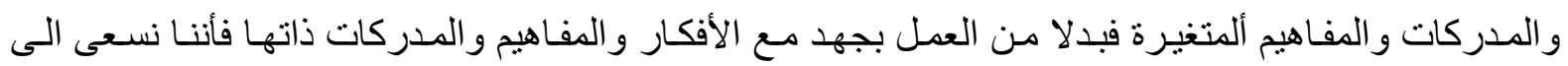
تغيير ها وكذلك توليد مفاهيم ومدركات جديدة . (debono, . . . V,p . . و الناتج النهائي هو أفكار ومدركات ومفاهيم قابلة للتطبيق في المجالات التي تحتاج الى التفكير ، و الأعمال التي نقوم بها لا بمكن ان تتم بشكل أوتوماتيكي وروتيني فهناك حاجة لبعض المهارات في التفكير الاحاطي (الموسوي ،9 ، . ب،صبr). 
و هنالك عدد من الدراسات التي تناولت موضوع التفكير الجـانبي منها دراسـة (الجور اني • ( • ب) التي

أنثارت الى وجود علاقة داله احصائيا بين التفكير الجانبي و الانفتاح على الخبرة (كسمة من سمات الثخصية) اذ ان حدوث التفكير الجانبي يتطلب التحرر من القيود والعادات والميل الى التخيل و التجريد و التجديد في الحياة

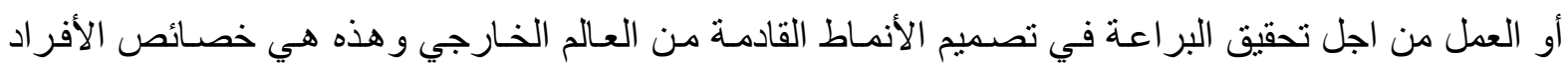

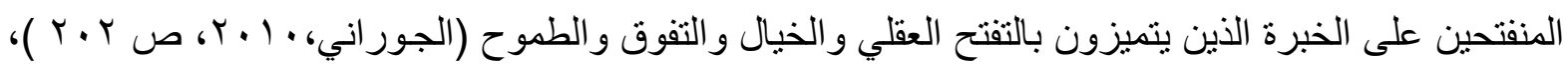

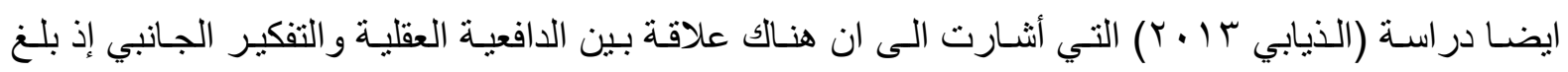
معامل الارتباط ببين الدرجـة الكلية للمتغيرين (جب, • ) و هو معامل ارتباط موجب و و عـال، وتعد هذه النتيجة

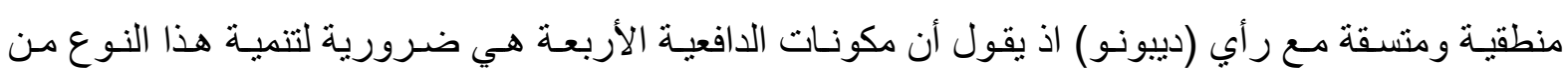
التفكير أو الإبداع الجاد، ويُعدها من مصسادر التفكير الجانبي الأساسية ولذلك ارتبطت مكونـات الدافعيـة العقلية بمعاملات ارتباط موجبة وجيدة بالدرجة الكلية للتفكير الجانبي، إذ كان التوجه نحو التعلم أكثر المكونات ارتباطاً

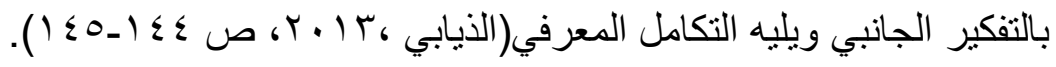
وتأتي الحاجـة الى تعليم التفكير في الوقت الحاضـر أكثر من أي وقت مضسى لان العـالم أصبح اكثر

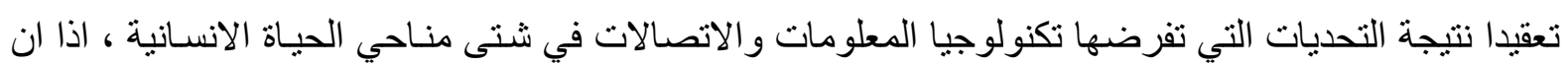

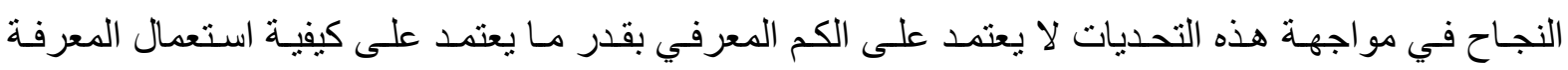

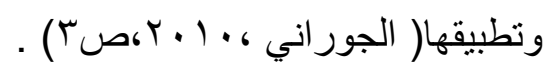

لذا ينبغي الاهتمام بمفهوم كفاءة المواجهة ليصبح مصدر الاهتمـام في حياة الأفراد سواء الذين مروا

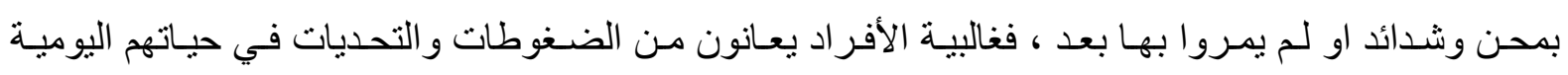

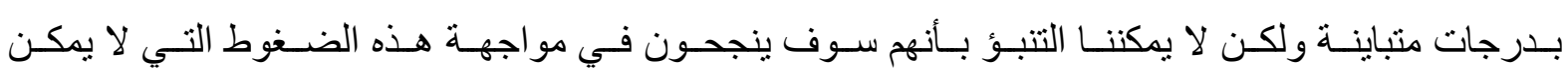

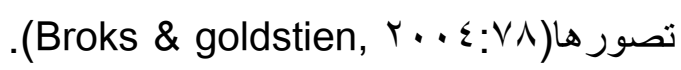

حيث ان كفاءة المو اجهة تعود الى التوجه العقلي ورؤية مؤداها لا يوجد احد لديـه مناعة ضد الضـغوط في بيئتنا المليئة بالتونرات ، لذلك لابد من الاهتمام في هذا المجال بتحديد المتغيرات التي تبني كفاءة المواجهة

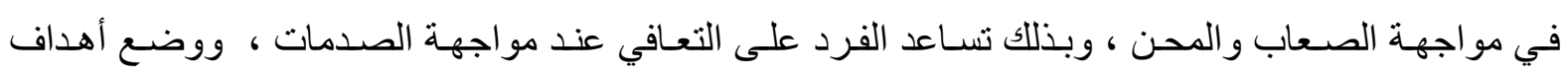

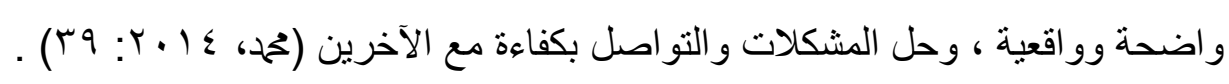

و ان أهم ما يميز فرد عن أخر هي القدرة على التكيف حيث تدل على امتلاك الفرد لطر ائق ووسـئل

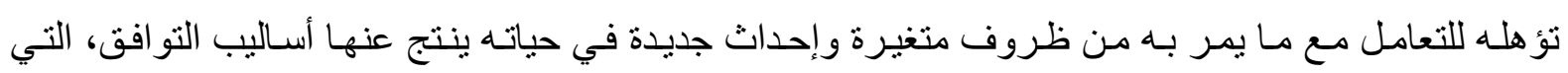
تساعده على كيفية التعامل سلوكيا ومعرفيا مع هذه الأحداث، فبعض عو امل الحياة تتكل عبئا على أنماط معينة من الثخصيات في حين تسنطيع أنماط أخرى تحملها ومن ثم التعامل معها بالثكل الذي لا يترك أثر الدى الدى

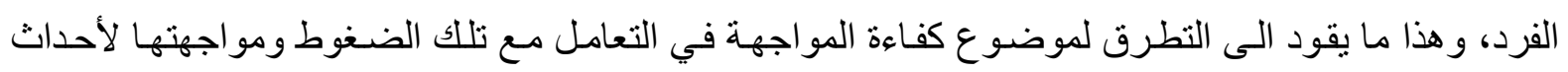

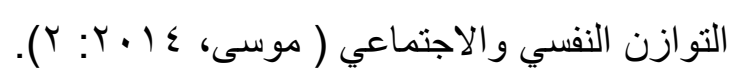




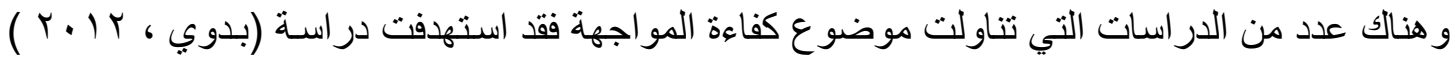
الدافعية المدرسية و إدر اك بيئة الفصل الدراسي لمرتفعي ومنخفضي كفاءة المواجهة وكانت عينة الدراسـة مكونـة من ( • ع Y) طالبا وطالبة، وقد توصلت الدراسة الى وجود فرق ذو دلالة إحصائيا في الدافعيـة المدرسية و إدراك بيئة الفصل الدر اسي بين مرتفعي ومنخفضسي كفاءة المواجهة ولصـالح مرتفعي كفاءة المواجهة ، كما وجدت علاقـة ارتباطيـة دالـة إحصـائيا بين كفـاءة المواجهة والدافعيـة المدرسية و إدر اك البيئة الصفية لـيهم (بدوي ،

.$(r: T \cdot 1)$

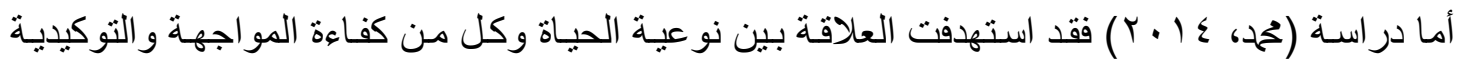

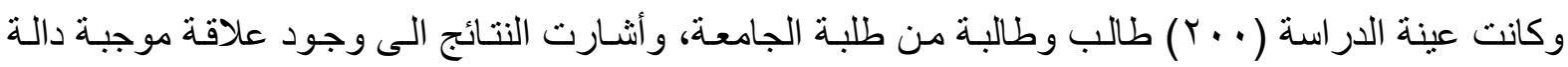
إحصائيا بين نوعية الحياة وكفاءة المواجهة وكذلك علاقة موجبة بين كفاءة المواجهة والتوكيدية لدى الطلبة، كما أظهرت الدراسة عدم وجود فروق دالة بين الذكور و الإناث في كفاءة المواجهة، كما أثنارت الدر اسـة الى إسـهام

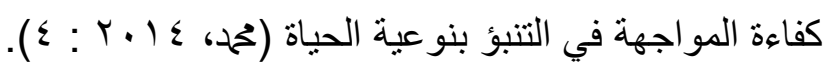
ثانثا: اهداف البهحدة

$$
\text { يستهدف البحث التعرف على : }
$$

1 - التفكير الجانبي لدى طلبة معهد الفنون الجميلة.

r - كفاعة المواجهة لدى طلبة معهد الفنون الجميلة.

r- العلاقة بين التفكير الجانبي و كفاءة المواجهة لدى طلبة معهد الفنون الجميلة.

رابعا: حدود البهحث

يتحدد البحث الحـالي بطلبـة معهد الفنون الجميلـة في محافظة القادية ، من الذكور و الانـاث ، للعـام

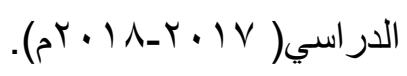

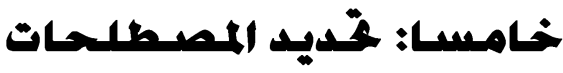

1- التفكير الجانبي: عرفه (ديبونو 991 (1) بانه: طريقة مبدعة وتخيلية في حل المشكلات تؤدي الى تغيير

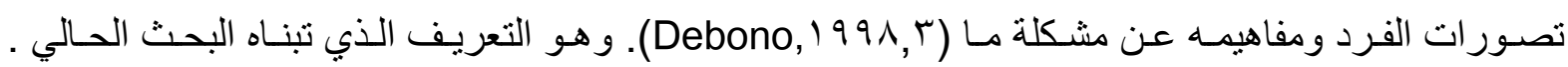
ويعرف البحث الحسالي التفكير الجـانبي اجرائيا بانها : الدرجة التي يحصل عليها الطالب عند الاستجابة على مقياس التقكير الجانبي . r- كفاعة المواجهة: عرفه (ويجنلند ويونك ب99 (1) بانه : خصائص الثخصية التي تساعد الفرد على ان يرفع

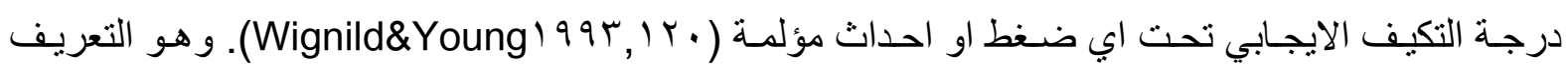
الذي تبنـاه البحث الحسالي ـ ويعرف البحث الحسالي التفكير الجـانبي اجر ائيا بانسه : الدرجـة التي يحصل عليها

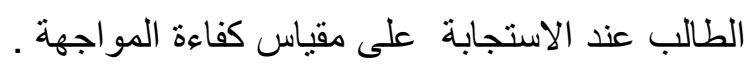


يعد البروفسور (دييونو) هو مبتكر مصطلح التفكير الجانبي (lateral thinking)، الذي دخل قاموس اكسفورد في طبعاته الاخيرة واختص (دييونو) في الفسلجة وعلم النفس ونـال درجه الدكتور اه في الطب ثم الدكتور اه في علم النفس من جامعه كامبرج البريطانية ، ونشر (ديبونو) اكثر من (TV) كتابـا يدور اغلبها حول

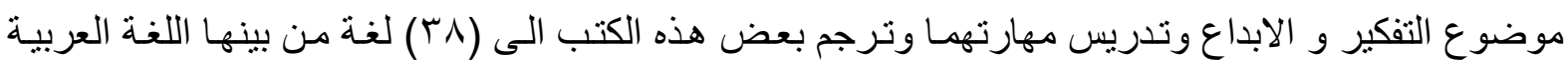

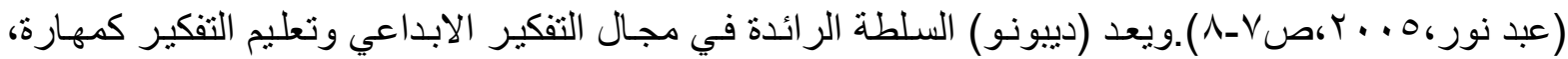
و هو الذي قام بوضع الادوات الابداعية الرئيسية للتفكير الجانبي، وهو ايضـا مكتشف استراتيجية القبعات الستة

للتفكير ( De bono, r. . . .

وقد اسمى (دييونو) هذا النوع من التفكير بـ(التفكير الجانبي) ليميزه عن نوع اخر من التفكير اسماه بالتفكير العمودي الذي يستتد اساسا الى المنطق او ما بالفه الانسان ويعتاد عليه. و وعد (ديبونو) هذا التفكير الذي لهي ينظر الى مشكلة ما من زوايا مختلفة بدلا من الالتزام بخط مباثشر للسير في البحث ، اذ يتجهـه هذا النوع من التفكير للإحاطة بمختلف وجهات النظر الاخرى بل ينطلق بعيدا عما هو مألوف في التفكير لذا يعد اسلوبا

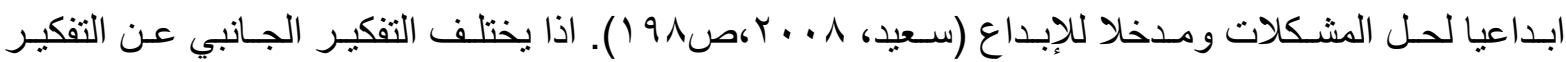
العمودي بطريقة الانتقال من مرحلة الى اخرى ، فعندما نأخذ مجمو عة مكعبات ونبنيها فوق بعضهها نجعل كل واحد يرتكز بشكل راسخ على الاخر ويشكل هذا الارتكاز التعليل الدقيق للتفكير العمودي ، امـا التفكير الجـانبي فتكون المكعبات مبعثرة هنا و هناك تربطها علاقة ضعيفة ان لم تكن معدومة لكنها بالنهاية تتمتع بنموذج لا يقل فائدة عن النموذج العمودي، الا انه يصعب علينا ادر الك التفكير الجانبي قبل ظهور نتائجه بشكل عملي ( ديبونو

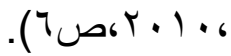
وتعددت مسميات التفكير الجانبي على وفق وجهة نظر (دييونو) و العلماء التربويين والنفسيين ومن تلك التسميات: التفكير الجانبي، التفكير الجوانبي ، التفكير الإحاطي ، الإبداع الجاد ، التفكير المتجدد ، التفكير خـارج Lateral ( الصندوق. ومن هنا ننطلق لتوضيح كل مسمى وتداخله مع الآخر :- اذ جاءت تسمية التفكير الجانبي ، Thinking من العـالم (ديبونـو) وهي التسـية الاكثر استخداما مـن بقيـة التسميات مـن التربويين و النفسبيين وبالمقابل جاءت تسمية التفكير الجوانبي فيرى مترجمو كتاب تعليم التفكير لـ (ديبونو ـ. . ب) بأنها الترجمة الاصح وهي اكثر اتصـالا للمفهوم اذ ان كلمـة الجـانبي تدل للوهلة الاولى على امر ثانوي لا قيمـة لـه. ولكن يمكن القول ان كلمة الجو انبي هي جمع تكسير لكلمـة جانب وهي تثشير الى التعددية في أكثر من جانب ولو رجعنا الى كلمة (Lateral) فهي كلمـة بصيغة المفرد لا بصيغة الجمع وبنـاء عليه فأن تسمية التفكير الجانبي أكثر ملائمة من التفكير الجو انبي. 
أما التفكير الاحاطي وهو ذلك النوع من التفكير الذي يسعى الى الاحاطة بجو انب المشكلة التي يجابهها في البحث عن حلولها و هذا الاسم يشابه الجو انبي في المعنى ولكن يختلف معه في الصياغة اللغوية. امـا التسميات الاخرى كالإبداع الجـاد و التفكير المتجدد استخدمها (ديبونو) بوصفها مر ادفات للتفكير الجـانبي في كتاباتـه فعندما يذكر الابداع الجـاد او التفكير المتجدد يقصد بـه التفكير الجـانبي والعكس صحيح

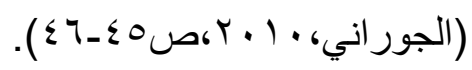

ويعد التفكير الجانبي بمثابـة نمط من التفكير يعتمد على ابتكار أكبر قدر ممكن من الحلول والبدائل، ويمكن من خلال التفكير الجانبي النظر إلى أكثر من جهة في المشكلة أو الموقف، والققز بخطوات حل المشكلة

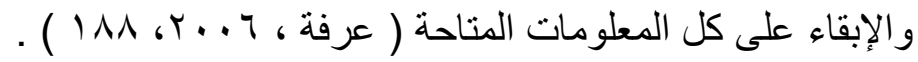

فعندما يفكر الثخص تفكير ا جانبيا فانه يضع أمامه العديد من وجهات النظر. و وكلها تعد صحيحة ويمكن التعايش معها. ولم تشتق تلك الرؤى من بعضـها البعض و إنمـا تم تكوينها بشكل مستقل. وفي هذا المعنى فإن التفكير الجانبي يعمل لاكتشاف الأمور تماماً كما يفعل التفكير الإدر اكي. ويمكن تمثيل ذلك بمن يقوم بأخذ صور لمبنى ما من عدة زوايا فتكون كلها متساوية من حيث الصلاحية.

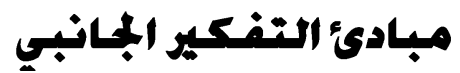

ثمة مجمو عة من المبادئ الاساسية لنظرية التفكير الجانبي يمكن اجمالها في النقاط الاتية :-

$$
\text { 1- التعرف الى الأفكار المتسلطة التي تستقطب باقي الأفكار. }
$$

r- البحث عن اختيار ات إدراكية بديلة عن الرؤية الأحادية التي تحددت في المبدأ الأول.

r- - الهروب من قبضة المنطق المسيطرة على عمليات التفكير ،لأن المنطق لا يأتي بأفكار جديدة. ع-استخدام الصدفة أي إدخال عنصر من العشوائية و المفاجأة لتجديد الأفكار،و عنصر الصدفة هو مناقض

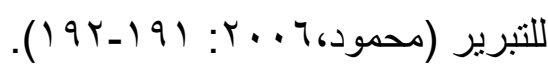

$$
\begin{aligned}
& \text { 0- التفكير الجانبي ليس موهبة موروثة . } \\
& \text { 7- التفكير الجانبي نمط من انماط التفكير يمكن التدريب عليه و اكتسابه . } \\
& \text { V- - - التفكير الجانبي مغاير للتفكير المنطقي ومتجاوز عنه . }
\end{aligned}
$$

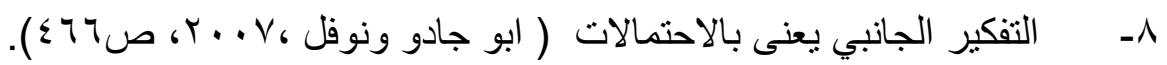

9 - تاجيل الحكم و التقييم حتى يتم الانتهاء من توليد عدد كبير من البدائل ، و التقييم هنا يشمل التقييم بنوعيه

$$
\text { الايجابي و السلبي . }
$$

• اـ الانطلاق في تسجيل الافكار التي ترد الذهن مهما كانت هذه الافكار حتى وان كانت غير تقليديه فقد تكون هي المنفذ لظهور بدائل جديدة . 


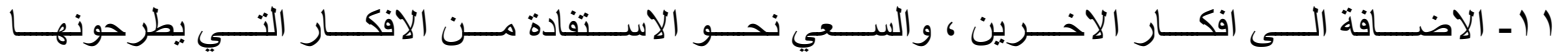
كنقة بداية لتنشيط تفكيرنا و ادر اكنا لعلاقات جديدة (Kim\&Darwin, . . . V,p^r)

\section{تخانيا/ كفاعة المواجهـة}

مفهوم كفاعة المواجهة

يعد مفهوم كفاءة المواجهة من المفاهيم التي ارتبطت بدر اسات علم النفس الايجابي ، إذ يستمد كل منهمـا جذوره من القوى الإنسانية ، فقد أنثار (روس نيومـان . . . ب) الى ان كفاءة المواجهة هي عملية مستمرة من

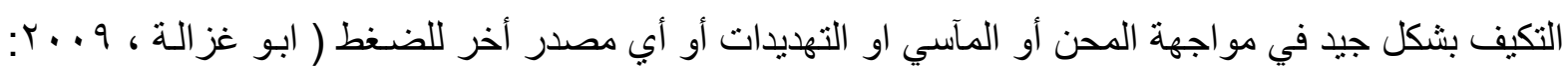

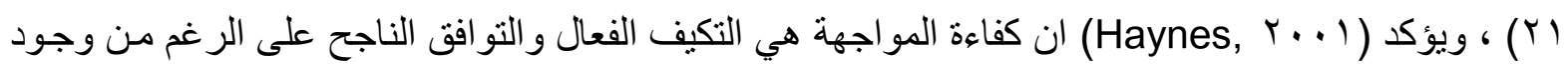

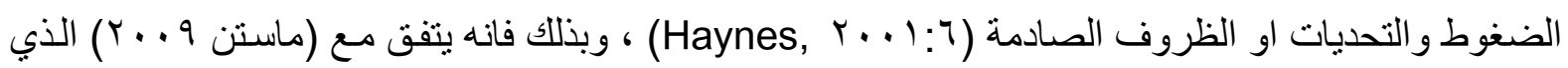
يرى ان كفاءة المواجهة هي القدرة على التكيف مع الضـوط النفسية وتكمن في أداء الفرد لوظائفه بشكل جيد . (r)

أما (Rutter, / 9 (أنه أثنار الى ان كفاءة المواجهة تنشأ وتتأثر بالعديد من عمليات التفاعل بما في ذللك العلاقـات الثخصـية والـدعم الاجتمـاعي الذي يتجـاوز الخصـائص الفرديـة وفي مختلف الفئـات العمريـة و السياقات (Costa et al , r (0:71).

وترى كرستمر (Krismer, Y . 0 ان كفاءة المو اجهة هي عملية بناء تنطوي على معنى ايجابي للحياة حيث يمكن تتميتها في الأفر اد من خلال تنمية الخصائص و السمات العديدة التي يتسم بها الفرد ، و لاسيما لدى الثباب الجامعي ، كما ترى ان كفاءة المواجهة قدرة تبزغ لدى الفرد والمجتمع و لاسيما في مواجهة الثدائد . (Krismer, $, \ldots 0: 1 Y)$

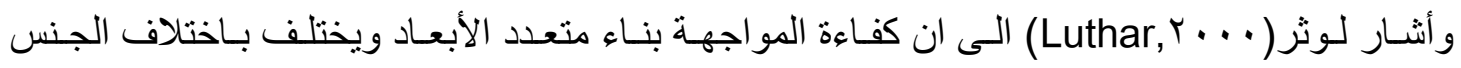

والوقت و العمر والبيئة الأسرية ونظم الدعم الاجتمـاعي والثقافة ، فضـلا عن القدرات الفرديـة ( Luthar et al

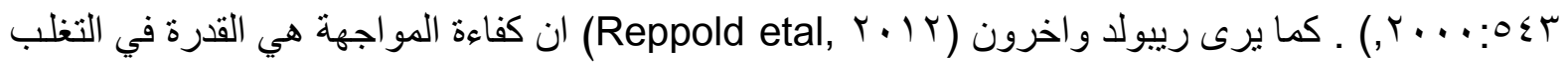
بنجـاح على المشكلات والظـروف المعاكسـة والتي تشـكل خطر على رفاهيـة الفرد ونمـوه وصــنه النفسية

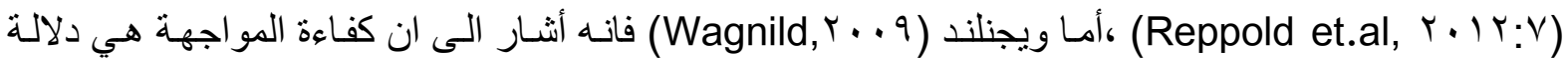

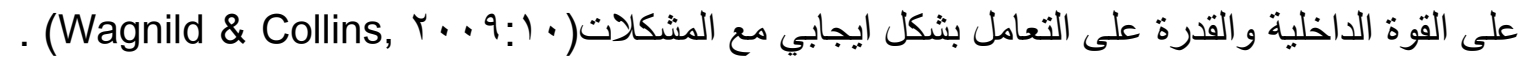




\section{نشأة مفهوم كفاءة المواجهة}

بدأ استعمال هذا المصطلح في الخمسينات ، و أصبح مفهوما واضحا كخاصية شخصية وتساعد الأفر اد على التكيف والتوافق مـع المو اقف التي يتعرضسون فيها الى ضـغوط عصيبة او لسوء معاملة (أبو غزالة ،

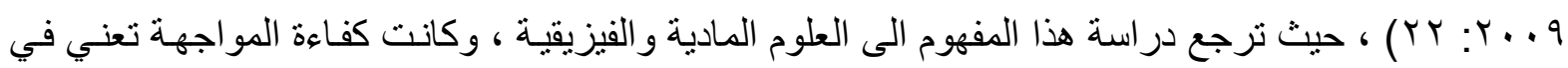
هذا المجال بأنها ( الخاصية التي تتمتع بها المو اد وتمكنها من استعادة شكلها او وضعها الأصلي بعد مـاتم

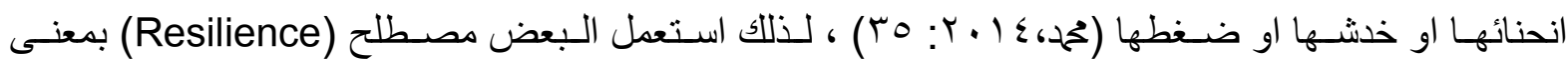
(المرونة) أي ان الثيء قابل لاستعادة وضعه بسرعة . أما في العلوم الإنسانية فتم تناولها على إنها (العمليات الديناميكية المشتملة على التكيف الايجابي بالر غم من الخبرات الصادمة او المؤلمة) (بدوي، ب ا ـ ؟: ( ) . حيث تم تناول هذا المصطلح في السبعينات في مجال العلوم الاجتماعية والإنسانية وكان الرائد في هذا

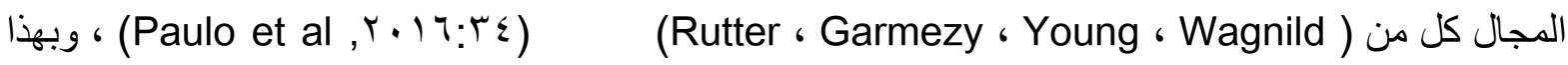
فان كفاءة المو اجهة' تعني عملية الصمود بشكل جيد أمام الصدمات و التهديدات و الأحداث الحياتية الضاغطة من جهة ، ومرونة المواجهة والتكيف مع هذه الضغوط من جهة أخرى ، لذلك فان مصطلح ( كفاءة المواجهة) يعد

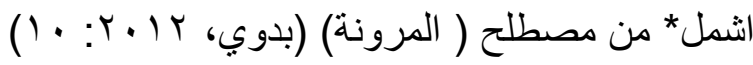

\section{مراحل تطور مفهـوم كفاعة المواجه}

الاهتمام بوصف الفرد :

اهتمت المرحلة الأولى بدر اسة طبيعة الشخصية الإنسانية و التعرف على المفاهيم و المنهجيات لفهم

الفروق الفردية في استجابة الأفر اد للمخاطر وتأثثر هذه المخاطر والمحن والضغوطه في الأفراد ، حيث ركزت الإنه الدر اسات في هذه المرحلة على كفاءة المواجهة بوصفها سمة شخصية تتركز بشكل خاص للى الأفر اد الذين يتغلبون على الثـدائد ( (1. Masten \& Garmezy, 1910$)$ ، ومن خلال السنوات الأولى للبحث في تطور كفاءة المواجهة تمت دراسة الظاهرة في مجالات مختلفة ومتنو عة ، وتم الاتفاق على مفاهيم مفتاحية ، و هي ان كفاءة المواجهة تثير الى نمط من التو افق الايجابي في إطار محنة وقت في الماضي او قائمة في الحاضر ، وقد اتفقو ا على :

الإقرار بوجود تهديد حقيقي لنمو الفرد وتو افقه .

الإقرار بأنه رغم التعرض للتهديد او المحنة فان الفرد يتمتع بتوافق جيد و لابد من وجود محك

موضوعي في الحالتين لوقوع الضرر وتحقق التوافق الجيد . ومن خلال نتائج الدراسات السابقة توصل الباحثون و العلماء الى حقيقة مفادها ان هناك أفر اد يستجيبون

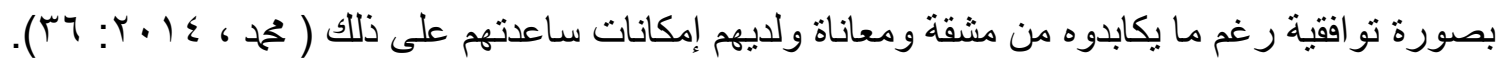




\section{الاهتمام بتفاعل الفرد ميع البيئات المختلفة :}

سـاهمت هذه المرحلـة والتي كانت سـائدة لاسيما خـلال التسعينات مـن القرن العشرين في فهم كفاءة المواجهة كعملية أكثر ديناميكية ناتجة عن تأثر الفرد بالآخرين وبالنظم التي ينتمي إليها كل شخص ، حيث تم الاهتمام بدر اسة كفاءة المواجهة داخل النظم الحياتيـة مثنل ( العلاقات مـع الآخرين ، دور الأسرة ، النظم داخل وخارج الأسرة ، دعم المعلمين ، الاهتمام بالعمليات البيولوجية والاجتماعية والثقافية ودمجها في دراسـات كفاءة المواجهة ) ، وقد تم اعتبار كفـاءة المواجهة مكونـا هامـا في مجال علم نفس النمو ، ومن هنـا جـاء الاهتمـام بدر اسة المصادر و الموارد الثخصية والاجتماعية والأسرية والتي تسهم في نمو كفاءة المواجهة و العمل على وضع برامج وقائية لتتمية وتعزيز تلك العو امل ، وبهذا نجد ان دراسـات كفاءة المواجهة انتقلت من الاهتمام

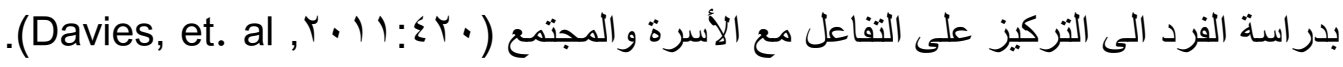

\section{تعزيز كفاعة المواجهة :}

منذ عام (1991 (1) بدأ التحول الى مجال علم النفس الايجـابي ليهتم الاهتمـام المباشـر بتنميـة الإمكانيات و القدر ات الكامنة في صلب تكوين الإنسان ومساعدته على الاستجابة المثلى و التصدي للضنغوطات ، وفي هذه المرحلة تم التركيز على تعزيز وتدعيم كفاءة المواجهة من خلال بر امج الدعم او المسـاندة الاجتماعيـة ومقاومـة

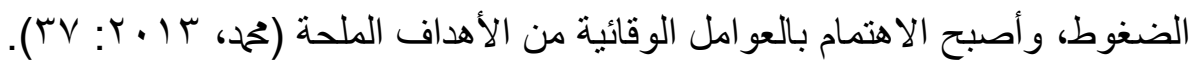

\section{البحموث والدوراسـات :}

تشير هذه المرحلـة الـى تعمق البحوث في كفاءة المواجهة على مستوى النظم المتعددة ، و العمليـات العصبية الحيويـة، حيث تـم تقديم أبحـاث جديدة ومتعددة في اختصاصـات مختلفـة منـل (علم الور اتــة وعلم

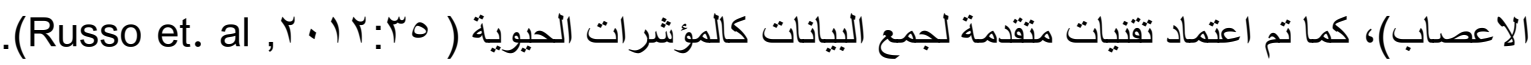

\section{خصسائم الأفراد ذوي كفاءة المواجهة}

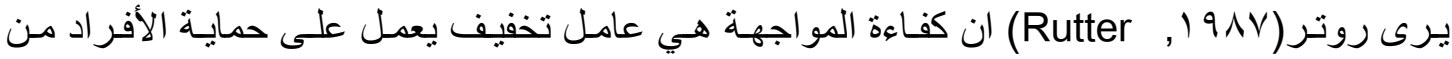
الاضطر ابات النفسية، لذلك فان الأفر اد ذوي كفاءة المواجهة يتمتعون بخصـائص عديدة، كاحتر ام الذات، و التقة

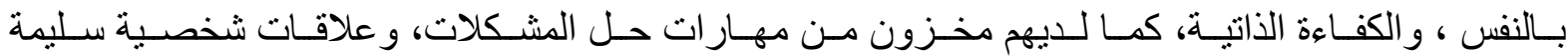

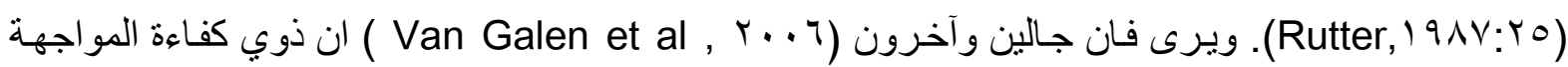
العالية يتميزون بالخصائص و السمات الاتية:

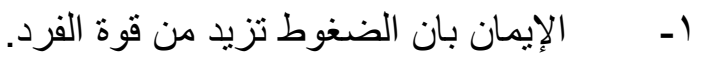

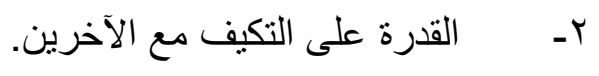

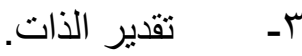

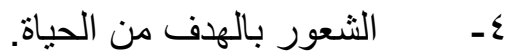




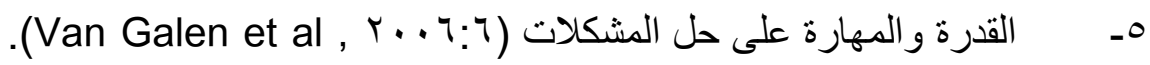
نموذج ويجنلند ويونك سو 199 في كفاءة المواجهة

يرى كل من ويجنلند ويونك (Wagnild \&Young ) ان كفاءة المواجهة هي إمكانيـة الفرد في التعامل بنجـاح مـع التغير او المشقة ، فـالأفراد ذوي كفـاءة المواجهة يستمرون على الرغم من المحنـة والاضطر اب

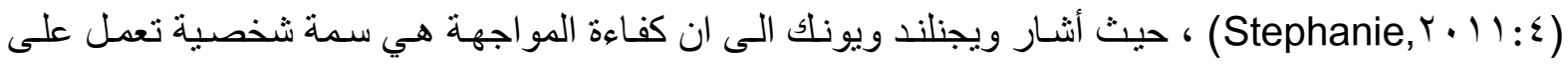
خفض الآثار السلبية للتوتر والتحفيز على التكيف والتناغم مـع حياتهم وتجنب أنار التدهور المحتملة للتوتر . (Wagnild \& Young, 199\%:170)

ويتفق رأي ويجنلند ويونك مع رأي ماستن ( Masten, . . (Mندما أنـار الى ان كفاءة المواجهة إنها

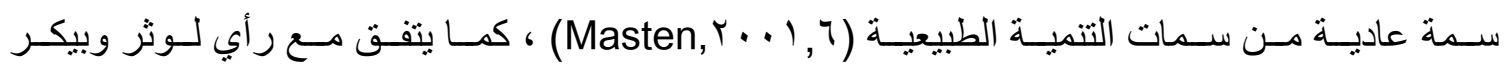
(Luthar\&Becker, r...)

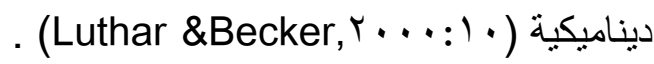
كما أوضح (ويجنلند ب . . r) ان كفاءة المواجهة سمة فطرية ويمكن لأي شخص ان يمتلكها الى حد مـا،

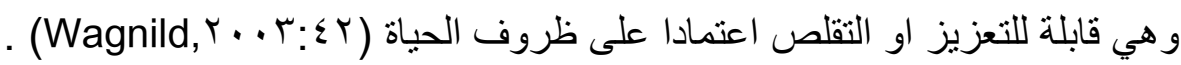

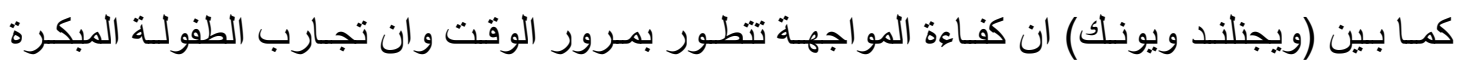
كالعلاقات العائلية الوثيقة ، و النمـاذج التي يقتدي بها الطفل تتمي لديه التقة و الاعتمـاد على النفس ، تسـهم في

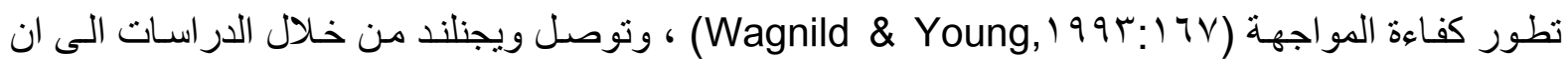
كفاءة المواجهة ليس لها عمر محدد ، كمـا إنها لا تتأثز بطبيعة تعليم الفرد ، كمـا أشـار الى ان كفاءة المواجهة

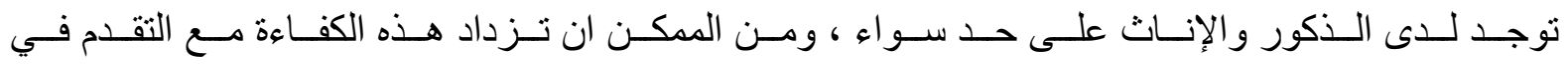

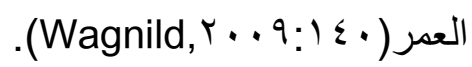

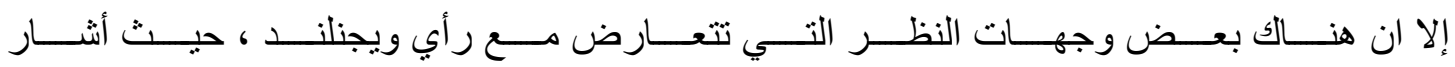

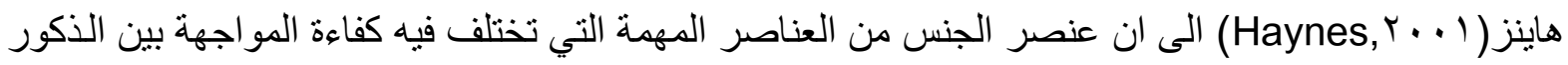
و الإناث ، حيث توصلت دراسته الى ان كفاءة المواجهة ترتفع لاى الإناث في مرحلة الطفولـة أكثر من الذكور وتنخفض لديهن في مرحلة المر اهقة ، ولهذا فانـه أثنـار الى ان كفاءة المواجهة عملية ديناميكيـة تتغير عبر 


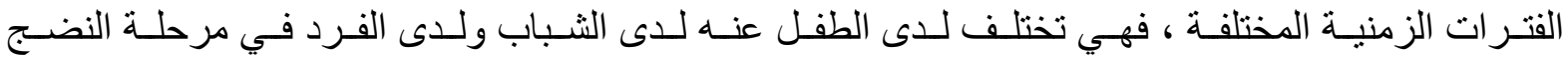
. (Haynes,, . . I: $: 00)$

\section{تطور مقياس كفاعة المواجهة لويهنلند ويونك}

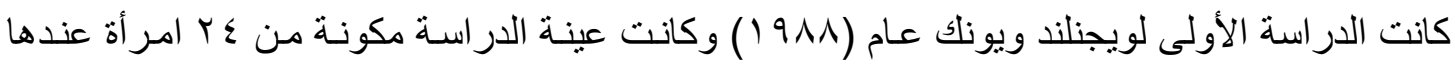
كان المقياس الأولي مكونا من (Y0) فقرة موزعة على عاملين هما: ( الكفاءة الثخصية ، وتقبل النفس والحياة) (Wagnild \& Young, 199 ، و تم إضافة فقرة أخرى الى المقياس لاحقا ، وبذللك أصبح مكون من 19 ) (YT) فقرة ، وبعد إجر اء در اسـة لتحليل عوامل المقياس ، أظهرت نتائج الدراسـة توزيع الفقرات على خمسـة مكونات او أبعاد للمقياس وهي :

1 - المعنى: ادر الك الفرد للهدف من حياته وقيمته الثخصية ، و الإحساس بالموضو عات التي يستحق العيش من اجلها . r- - الاتزان: نظرة الفرد المتوازنة نحو الحياة وقدرته على النظر من خلال مجموعة واسعة من الخبرات بهدف تخفيف الاستجابات المتطرفة نحو الثدائد.

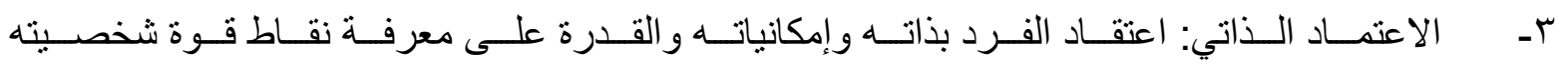
.(Wagnild, $r \cdot q: r v)$

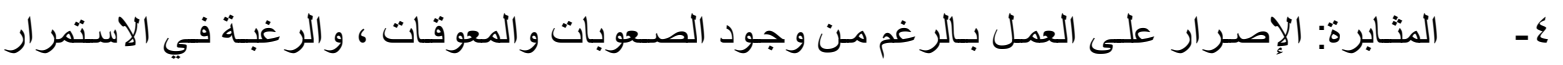
و الكفاح من اجل إعادة المشاركة وممارسة الضبط الذاتي . 0ـ الوحدة الوجودية: لكل فرد مسار فريد في حياته الذي يضفي عليه شـور ا بالحريـة والإحساس بالتفرد

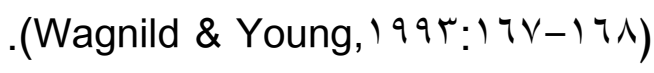

\section{منهـبية البحدث وإجراءعاته}

أو لا: مجتمع البحث / يتكون مجتمع البحث الحالي من طلبة معاهد الفنون الجميلة في محافظـات الديوانية والحلـة

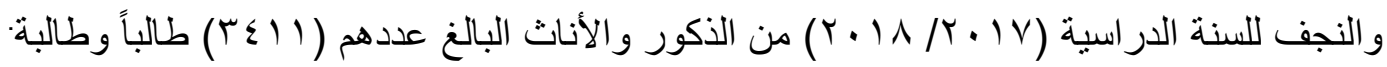
ثانيا: عينة البحث

تم اختيار عينة البحث الحالي بالطريقة الطبقية العشوائية ، و البالغ عددها ( . ع ) طالباً وطالبة، بنسبة (r ا (\%) من المجموع الكلي لمجتمع البحث في الصفوف الخمسـة مـن معاهد الفنون الجميلـة في محافظـات

الديو انية والحلة والنجف، وكما موضحة في الجدول ( ('). الجدول (1) عينة البحث موزعة وفقاً للمحافظة والمعهز والقسم والفرع

\begin{tabular}{|c|c|c|c|c|c|c|c|c|}
\hline \multirow[t]{2}{*}{ المجموع } & \multirow{2}{*}{ والزخرفة } & \multirow[t]{2}{*}{ التصميم } & \multicolumn{4}{|c|}{ التشكيل } & \multirow[t]{2}{*}{ القسم } & \multirow[t]{2}{*}{ لمحافظة } \\
\hline & & & الرسم & النحت & الكرافيك & الفخار & & \\
\hline 14 & 17 & 11 & 17 & 11 & 11 & $1 \leq$ & معهد الفنون الجميلة/ للبنين & \multirow[t]{2}{*}{ القادسية } \\
\hline 71 & 10 & IV & 10 & 9 & 9 & 1. & معهد الفنون الجميلة/للبنات & \\
\hline
\end{tabular}




\begin{tabular}{|c|c|c|c|c|c|c|c|c|}
\hline Tr & 1. & $\mathrm{~V}$ & 11 & 9 & 9 & 9 & معهد الفنون الجميلة/ للبنين & الطلة \\
\hline 7. & 9 & 7 & 11 & 11 & 1. & 14 & معهد الفنون الجميلة/للبنات & \\
\hline $7 \varepsilon$ & Ir & Ir & Ir & 9 & 9 & 1. & معهد الفنون الجميلة/ للبنين & النجف \\
\hline 74 & 9 & ir & 9 & 1. & 11 & 11 & معهد الفنون الجميلة/للبنات & \\
\hline$\varepsilon \ldots$ & 79 & $v$. & $\checkmark \wedge$ & $\leqslant 1$ & $\Delta \wedge$ & TV & & المجموع \\
\hline
\end{tabular}

\section{مقياس التفكير الجمانبي}

- وصف المقياس/ يتألف مقياس التفكير الجانبي من(·r) فقرة او لغز وعلى المستجيب حل هذه الالغاز

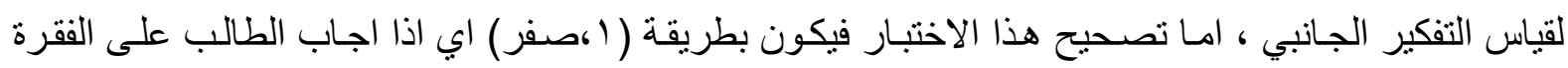

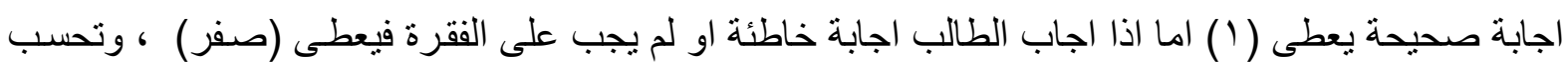
الدرجـة الكليـة للاختبـار بجمـع درجـات الفقرات الصحيحة وبذلك فـان اعلى درجـة يمكن ان يحصل عليهـا المستجيب هي (·r) و ادنى درجة هي (صفر) وبذللك فان الوسط الفرضي للاختبار هو (· ( ) .

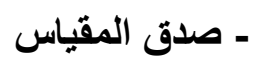
الصدق الظـاهري /تم عرض المقياس منضمنا تعريف (ديبونو ) للتفكير الجانبي ، على (Y) مـن الخبر اء التخصصين في مجال التربية وعلم النفس ، لبيان مدى صلاحية كل فقرة من فقرات المقياس ، وبيان

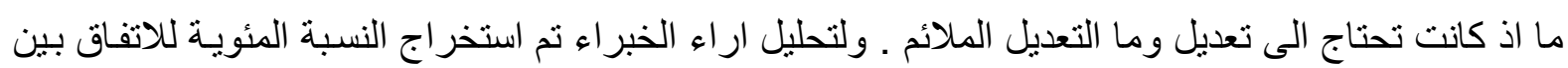

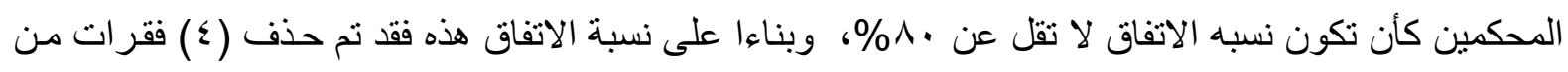

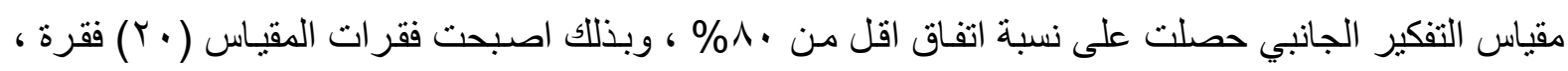

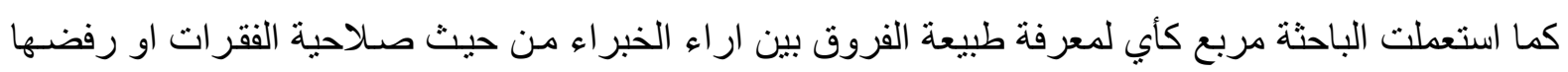

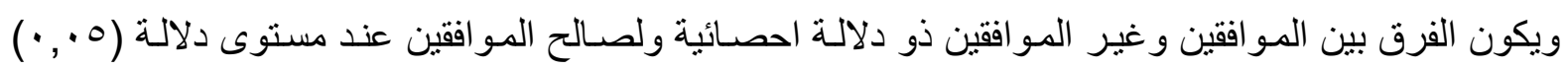

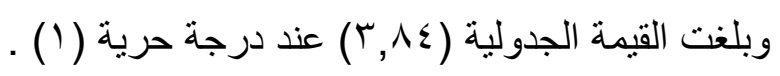

ا - صدق البناء / وقد تم التحقق من هذا النوع من الصدق من خلال المؤشرات الآتية :

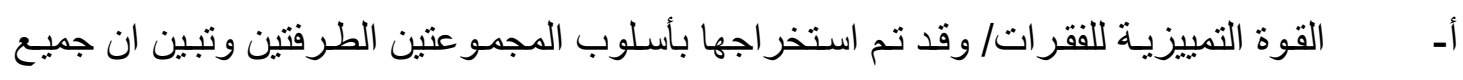

الفقرات دالة عند مستوى دلالة(0 . . ) وبدرجة حرية (ع (Y).

ب- علاقة درجة الفقرة بالدرجة الكلية للمقياس / لاستخر اج علاقة درجة الفقرة بالدرجة الكلية للمقياس

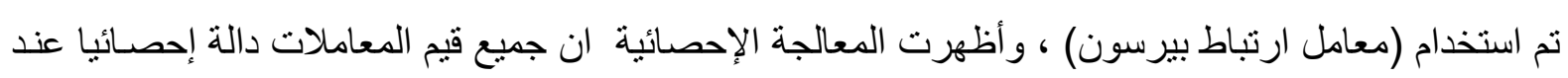

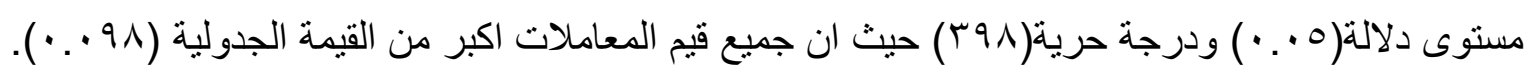

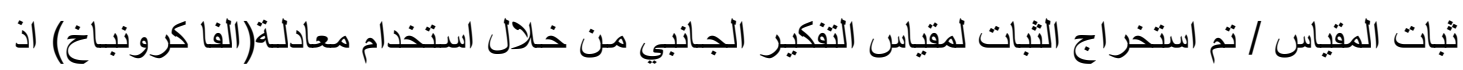

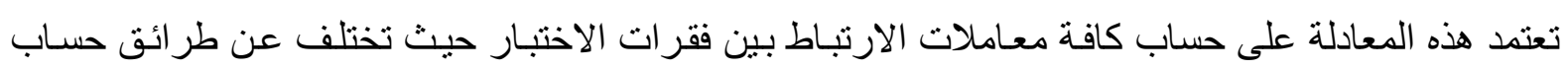

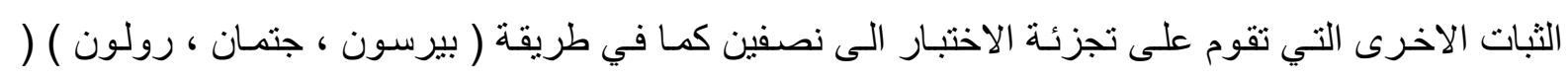

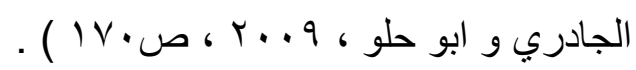


و لاستخر اج الثبات بهذه الطريقة طبقت معادلة (الفا كرونباخ ) على درجات افراد العينـة النهائية البالغ

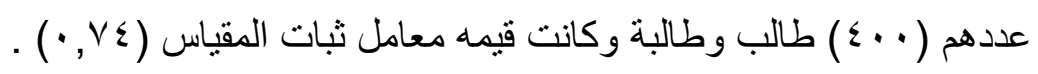

مقياس كفاعة المواجهة

ـ Wagnild \& تحديد مفهوم كفاءة المو اجهة / وجدت الباحثة من المناسب تبنـي تعريف ويجنلند ويونكـ بو لكفاءة المواجهة وهو (خصـائص الثخصية التي تسـاعد الفرد على ان يرفع درجـة التكيف

$$
\text { الايجابي تحت أي ضغط او أحداث مؤلمة). }
$$

- تحديد مكونات المقياس / نظر التبني مفهوم كفاءة المواجهة لويجنلند ويونك (ب9anild \& Young, 199) وبعد الاطلاع على الأدبيات وجدت الباحثة ان لكفاءة المواجهة خمسـة أبعاد هي: (المعنى،الاتزان، الاعتمـاد الذاتي، المثابرة، الوحدة الوجودية).

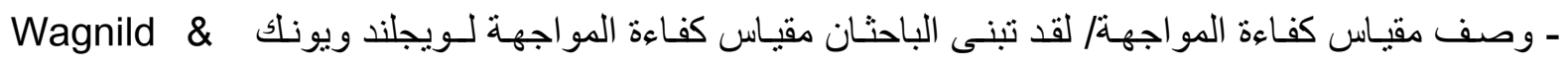

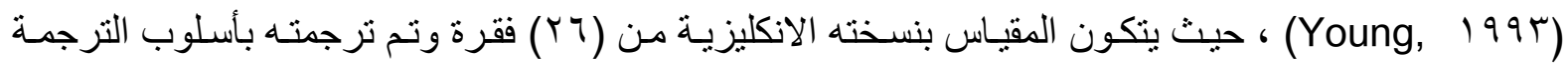
و الترجمة العكسية.

ـ التحقق من صـلاحية الفقرات / لغرض التعرف على صـلاحية الفقرات ، تـم عرض المقيـاس بعد الترجمـة

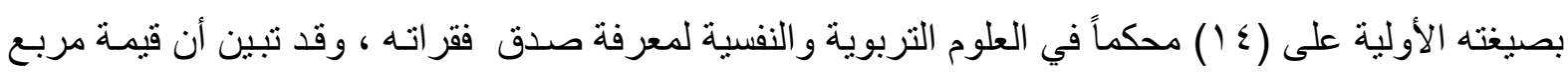

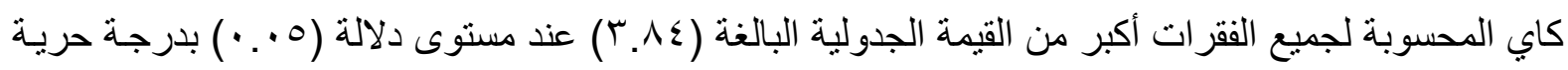

ـ طريقة تصحيح المقياس/ تم تحديد خمسة بدائل للاستجابة المتدرجة في المقياس وهي ( دائما ، غالبا ، أحيانا ،

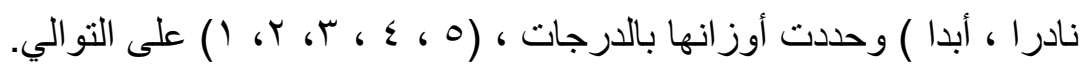

ـ التحليل الإحصـائي لفقرات المقياس / قامت الباحثة بـالتحقق من صدق وثبات المقيـاس للتأكد من صـلاحية لقياس متغير البحث.

ـ عينـة التحليل الإحصـائي / تألفت عينـة التحليل الإحصـائي من ( · . ؛ ) طالب وطالبـة تم اختبار هم بالطريقة الطبقية العشو ائية ذات التوزيع المتناسب . الخصائص السايكومترية لمقياس كفاءة المو اجهة

\section{هدق المقياس : م التحقق من هدق المقياس بالطرائق الآتية :}

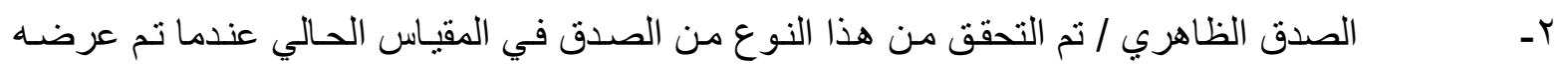
على مجمو عة من المحكمين المختصين في علم النفس للأخذ بآر ائهم بشأن صلاحية الفقرات . 
r- ـ صدق البناء / وقد تم التحقق من هذا النوع من الصدق من خلال المؤشرات الآتية :

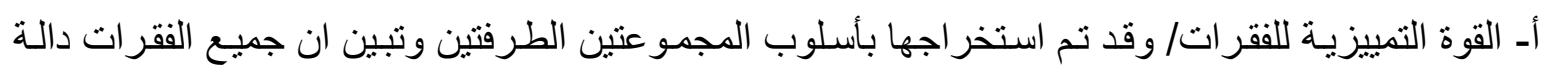

$$
\text { عند مستوى دلالة(0 . • · ) وبدرجة حرية (؟ (Y)). }
$$

بـ علاقـة درجـة الفقرة بالدرجـة الكليـة للمقيـاس / لاستخر اج علاقـة درجـة الفقرة بالدرجـة الكليـة للمقيـاس تم

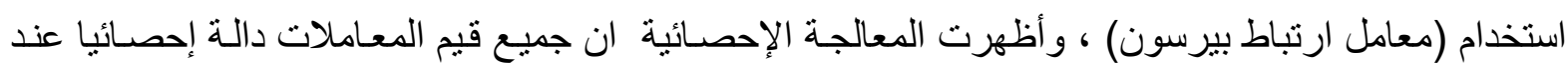

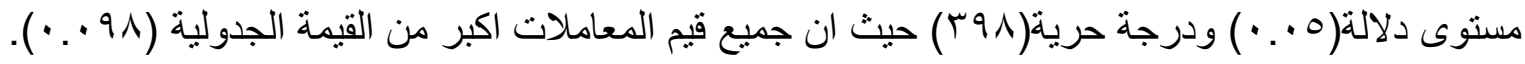
ج- علاقة درجة الفقرة بدرجة المجال الذي تنتمي إليه لـقياس كفاءة المواجهة/ لحساب علاقة درجة كل فقرة بالدرجة الكلية للمجال الذي تنتمي إليه، تم تطبيق معامل ارتباط بيرسون، وتبين أن جميع قيم المعاملات دالة إحصائيا عند مسنوى دلالة (0. . •) ودرجة حرية(191) حيث ان جميع قيم المعاملات اكبر من القيمة الجدوليـة

تم استخر اج الثبات لمقياس كفاءة المو اجهة بطريقة الفا كرونباخ حيث طبقت معادلة (ألفا كرونبـاخ)

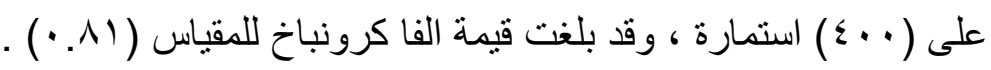

\section{التطبيةق الهنهائي}

تحقيق الأهداف البحث الحسالي وبعد ان تم التحقق من صدق وثبات المقياسين قامت الباحثنة بتطبيق المقياسين بصيغتهما النهائيسة على عينه التطبيق النهائي البالغـة ( . ـ ) طالبـا وطالبـة من طلبـة معهد الفنون الجميلة .

\section{عرض النتتائحج وتفسبيرهـا} الهُف الاول/ التعرف على التفكير الجانبي

لغرض التحقق من الهدف الأول الذي يرمي إلى التعرف على التفكير الجانبي لدى طلبة معهد الفنون الجميلة تم تحليل إجابات عينة البحث البالغة ( . . ع) طالبا وطالبة على مقياس التفكير الجانبي ، وجدت الباحثة

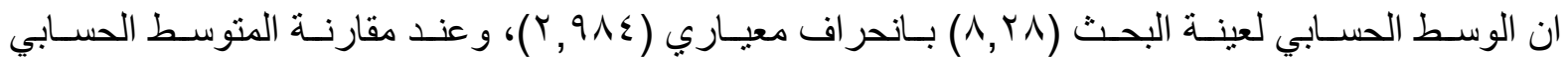
بالمتوسط الفرضي للمقياس البالغ (· ( )، وبعد اختبار دلالة الفرق بين المتوسطين باستعمال معادلة الاختبار التائي لعينة واحدة ظهر ان هنالك فرقا بين المتوسطيين وباتجاه المتوسط الفرضي، إذ أن القيمـة التائية المحسوبة

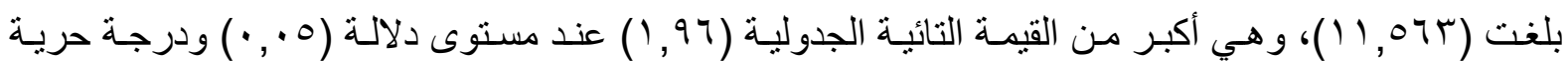


جدول(r (r) جأوساط الحسابية والفرضية لمقياس التفكير الجانبي

\begin{tabular}{|c|c|c|c|c|c|c|c|c|}
\hline \multirow{2}{*}{ مستو } & \multirow{2}{*}{ الحرية } & \multicolumn{2}{|c|}{ القيمة التائية (t) } & \multirow{2}{*}{ المتوسط الفرضي } & \multirow{2}{*}{ الانحراف المعياري } & \multirow{2}{*}{ المتوسط } & \multirow{2}{*}{ العينة } & \multirow{2}{*}{ المتغير } \\
\hline & & الجدولية & المحسوبة & & & & & \\
\hline دالة & rq9 & 1,94 & 11,07 & 1. & $\curlyvee, q \wedge \varepsilon$ & $\Lambda, r \Lambda$ & $\varepsilon \ldots$ & الجانبكير \\
\hline
\end{tabular}

و هذا يشير إلى ان الطلبة لا يتمتعون بالتفكير الجانبي ، وقد يعود ذلك الى طبيعة منـاهجهم التي تؤكد على الالتزام بنوع تفكير واحد من دون حث الطلاب على الخروج من النمط السـائد والخروج عن المـالوف ، و هذه النتيجة تتفق مع راي (دييونو) اذ يقول ان الانسان يفكر عاده على وفق قيود وحدود ترتبط باسلوب في التفكير ، وحدود ملاحظاته ومعار فه و الانماط و العادات التي الفها فهو محصور في انماط روتينية وتقليدية مقيدة

\section{الهدف الثاني/ التعرف على كفاعة المواجهة}

لتحقيق هذا الهذف تم تحليل إجابات عينة البحث البالغة ( . . ع) طالب وطالبة، ولمعرفة دلالة الفرق بين

$$
\text { المتوسطين الحسابي و الفرضي تم استعمال الاختبار التائي لعينة واحدة ، جدول( ب ) }
$$

جدول( بالأوساط الحسابية والفرضية لمقياس كفاعة المواجهة

\begin{tabular}{|c|c|c|c|c|c|c|c|}
\hline الالالة & الجذيمة T & المحسوبة & الانحرياري & الحسابي & الفرضي الوسط & عدد أفراد & لمقياس ومجالاته \\
\hline دال & 1.97 & $5 . .990$ & r.0V7 & Y^.rr. & YI & \multirow{6}{*}{$\varepsilon \ldots$} & الاتزان \\
\hline دال & 1.97 & $r \leqslant \leqslant \leqslant Y$ & r.MOY & Yr..9V & 11 & & المثابرة \\
\hline دال & 1.97 & r^.q^o & $r .9 \wedge 1$ & Yr.VV. & 11 & & الاعتمـاد الذاتي \\
\hline دال & 1.97 & $r \leqslant . r \wedge Y$ & Y.Alo & $10 . \leqslant M r$ & Ir & & المعنى \\
\hline دال & 1.97 & 5.711 & r..07 & Ir.V7o & 9 & & الوحدة الوجودية \\
\hline دال & 1.97 & $\varepsilon r . \leqslant \neg \wedge$ & $11 . \varepsilon \wedge \wedge$ & 1.r.rqo & $\vee \wedge$ & & المقياس ككل \\
\hline
\end{tabular}

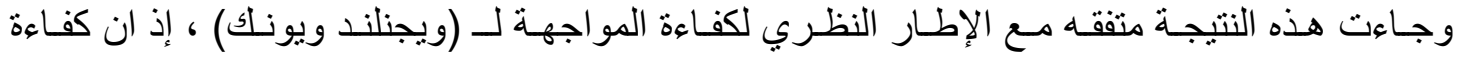
المو اجهة سمة فطرية ويمكن لأي شخص ان يمتلكها الى حد ما ، حيث إنها عملية ديناميكية تتحقق لدى البعض ره في سياق النمو ، كما إنها تزداد او تقل بالاعتماد على ظروف الحياة .

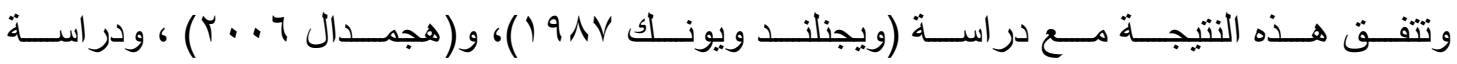

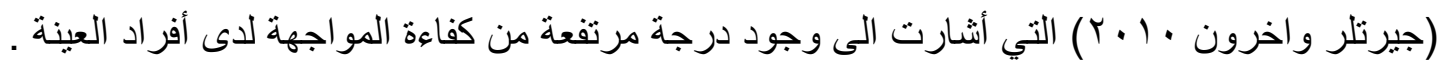

ونظر الكون كفاءة المواجهة سمة فطرية، لذلك يمكن تفسير هذه النتيجة بـان كفاءة المواجهة لا تحدث

فقط عندما يكون هناللك خطر يهدد حياة الفرد، وإنما يمكن ان تظهر في الكثير من مو اقف الحياة لذلك نجد ان طلبة المعاهد يتمتعون بهذه السمة، حيث من المككن ان تظهر كفاءة الطالب في مواجهة موقف تعليمي ما.

الهدف الثالث / التعرف على العلاقة بين التفكير الجانبي وكفاعة المواجهة لمعرفة العلاقـة الارتباطية بين المتغير المستقل (التفكير الجانبي) والمتغير التابع (كفاءة المواجهة)، وتبين بعد استعمال معامل ارتباط بيرسون ان جميع معاملات الارتباط اكبر من القيمة الجدولية (91 . .) عند 


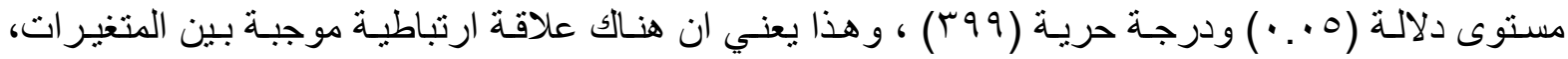
جدول (乏): ( )

جدول (؛ ) معاملات الارتباط بين التفكير الجانبي و كفاءة المواجهة

\begin{tabular}{|c|c|c|c|}
\hline مستوى الدلالة & القيمة الجدولية & معاملات الارتباط & معاملات الارتباط بين التفكير الجانبي ومجالات كفاءة \\
\hline \multirow{6}{*}{$\cdot, \cdot 0$} & \multirow{6}{*}{$\cdot, .91$} & 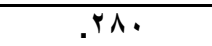 & الاتزان \\
\hline & &.$r \cdot Y$ & المثابرة \\
\hline & & .rT. & الاعتماد الأاتي \\
\hline & & $r \leqslant \Lambda$ & المغنى \\
\hline & &.$r \vee \Lambda$ & الوحدة الوجودية \\
\hline & & . & المقياس ككل \\
\hline
\end{tabular}

وجاءت هذه النتيجة متفقة مع ما ورد في الإطار النظري الذي أنشار الى وجود اتسـاق نظري بين

التفكير الجانبي كفاءة المواجهة .

التتوصسيات

1 - حث الطلبة على عدم التقييد بنمط محدد من التفكير وذللك من خلال اجر اء الندوات والدورات التدريبيـة التي تنمي لاى الطلبة مهارة التفكير الجانبي. r- عقد نـدوات تعمل على توعيـة الطلبـة بأهميـة كفـاءة المواجهة والتي تسـاعدهم على تجـاوز العقبـات و المو اقف الصعبة. |مادمر

ا - العتوم ، عدنان يوسف واخرون ،(7 + . ץ):علم النفس التربوي النظرية والتطبيق، طا ، دار المسيرة للنشر والتوزيع ،عمان - الاردن

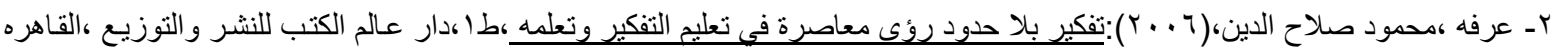

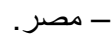

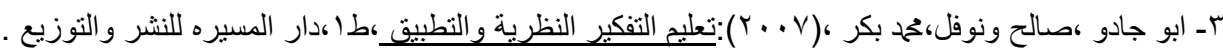

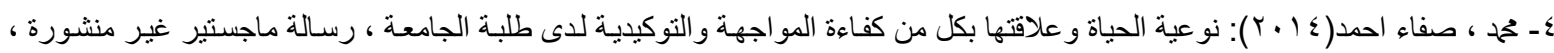

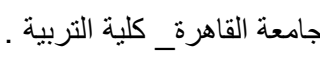

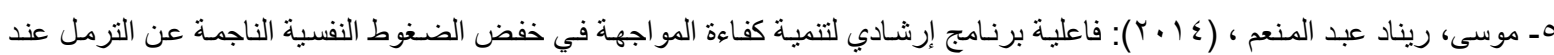

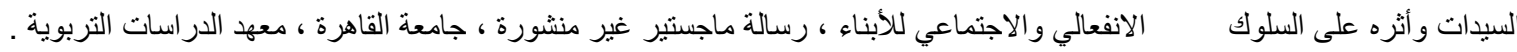

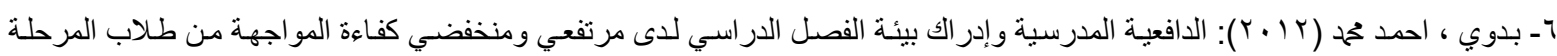

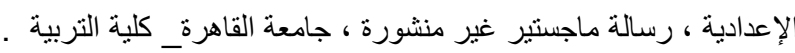

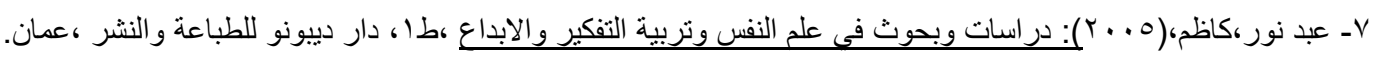

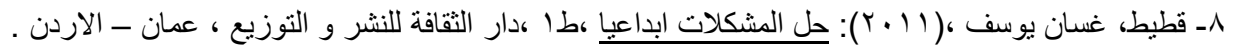

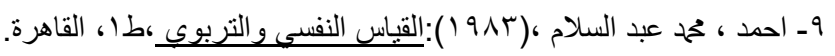

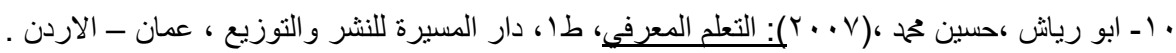

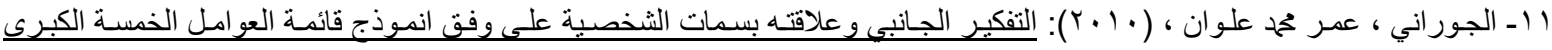

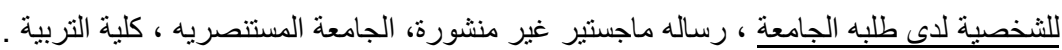

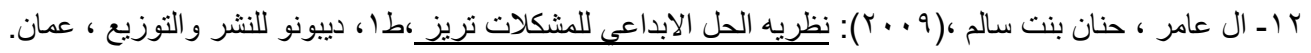

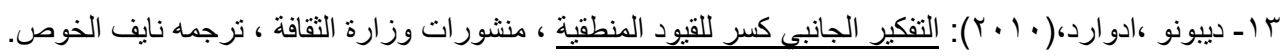

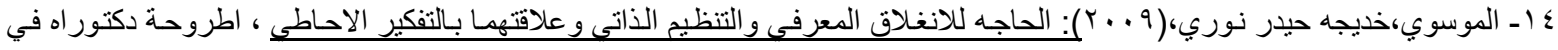




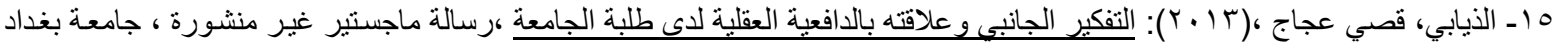
، ملية التربيه /ابن الرشد.

17- Brooks, Robert\& Goldstein , sam $(Y \ldots \varepsilon)$ the power of resilience achieving balance confidence and personal strength in your life , united state of America , MC Graw-hill.

IV- De Bono, Edward , $(Y \cdots \vee)$,how to havecreative ideas : $7 r$ exercises to develop the mind ,uk,London.

\^- De Bono, Edward ,( ( $9 \wedge \mathrm{r})$, Debonos thinking course. First published, London.

19-Wagnild, G \& Young, H (199\%). Development and psychometric evaluation of the Resilience Scale. Journal of Nursing Measurement, vol('), no(Y), $\mathrm{pp}(170-1 \vee \wedge)$.

$r \cdot-$ Costa, J, Maria ,d, Ana,p \&, Sara, A, $\left(r^{\prime} / 0\right)$, The Resilience Scale A study in a Portuguese adult sample, Faculty of Psychology and Educational Sciences, Research Centre of Cognitive and Behavioural Studies and Intervention, University of Coimbra.

Y)-Davies, S, Thind, R., Chandler, D \& Tucker, A (r.11) Enhancing resilience among young people: The role of communities and asset-building approaches to intervention. Adolescent Medicine, Journal of Nursing Measurement, vol $\left(T^{Y}\right)$.

Y $Y$-Krismer,M $(Y \cdots 0)$, attributes and support systems that promote resilience and achievement for at-promise community college students, ph.d thesis university of cinnari college of education u.s.a.

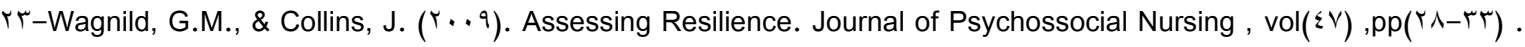
$r \leqslant-P a u l o, d$, Irene ,c \& Paulo,p $(r \cdot 1 \uparrow)$ further evidence for the structure of the resilience scale in Portuguese language countries an invariance study, journal of the Portuguese association of psychology, vol $(r \cdot)$.

ro-Masten, A \& Garmezy, N (1910) Risk, vulnerability, and protective factors in developmental psychopathology. In B. Lahey, \& A. Kazdin (eds.), Advances in clinical child psychology vol (^) New York.

Y -Luthar, S, Cicchetti, D, \& Becker, B. $(Y \cdots)$. The construct of resilience: A critical evaluation and guidelines for future work, Child Development, vol(r), $\mathrm{pp}(0 \leqslant r-07 r)$.

Y $\mathrm{V}$-Rutter,M ( $9 \wedge \mathrm{V})$ psychosocial resilience and protective mechanisms, American journal of orthopsychiatry, vol( $(\circ \mathrm{V})$ $, p p(r) \neg-r \mu \cdot)$.

ץ -Wagnild , G $(r \cdots r)$ Resilience and successful aging, Comparison among low and high income older adults, Journal of Gerontological Nursing,vol( $r q), \operatorname{pp}(\varepsilon r-\varepsilon q)$. 